\title{
Institutionalising federalism in Nepal: operationalising obstacles, procrastinated progress
}

\author{
Keshav Kumar Acharya \\ German Development Cooperation, Kathmandu, Nepal, and \\ Habib Zafarullah \\ University of New England, Armidale, Australia
}

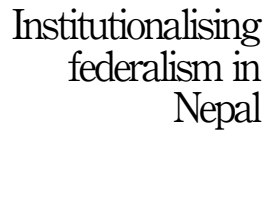

125

Received 10 March 2020

Revised 20 April 2020

Accepted 4 June 2020

\begin{abstract}
Purpose - The purpose of this paper is to explore how local government bodies in Nepal are empowered to play their constitutional roles and engage in activities to deliver public services at the doorsteps of the people effectively. The focus is on the institutionalisation of federalism, its implications for local governance, and capacity development of local authorities.

Design/methodology/approach - Ideas of decentralisation, governance and public management have been used to interpret findings based on qualitative research methods by key informant interviews, focus group discussions and personal observations conducted in five selected municipalities in Nepal.

Findings - The process of operationalising the power of local government bodies is more conventional and hierarchic. At the same time, the formulation and implementation of inclusive plans and budgeting are confined with certain formalities that do not necessarily allow citizens the space for voices. Federal government grants constrain fiscal jurisdiction and control over resource mobilisation. The mere preparation and administration of local government legislation and relevant by-laws have weakened the capacity of local government bodies.

Originality/value - From interpretation of first-hand data, this paper has identified the pitfalls of the federalisation process, the constraints deter the devolution of power to local bodies as well as the transformation of local governments into autonomous institutions in Nepal.
\end{abstract}

Keywords Federalism, Decentralisation, Local governance, Institutional capacity, Nepal

Paper type Research paper

\section{Introduction}

Developing societies in the post-World War II period were beleaguered with a range of problems in political/public management, including dysfunctional administration, bureaucratic pathology, disordered public institutions, and organisational and functional complexities in public service delivery (Escobar, 1988). By the late 1970s, several structural and pluralist approaches had emerged to address institutional problems and inefficiencies in local governance (Campbell, 1972; Peters, 2001, pp. 3-12). However, these approaches heightened state-centrism and concentrated greater administrative and legislative powers in the central government (Pankaj, 2007). The efficiency of the administrative system was impaired, and the top-down decision-making process bolstered upward accountability in the institutional structures. Simultaneously, corruption, cronyism, political interference, and infraction of the rule of law and human rights became systemic (Zafarullah and Huque, 2001). In the 1970s, it became apparent that the existing hierarchical system was unable to deliver

(C) Keshav Kumar Acharya and Habib Zafarullah. Published in Public Administration and Policy. Published by Emerald Publishing Limited. This article is published under the Creative Commons Attribution (CCBY 4.0) license. Anyone may reproduce, distribute, translate and create derivative works of this article (for both commercial and non-commercial purposes), subject to full attribution to the original publication and authors. The full terms of this license may be seen at http://creativecommons. org/licences/by/4.0/legalcode
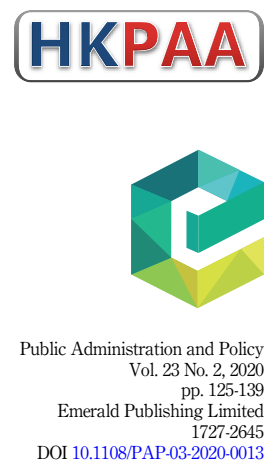
PAP

23,2

126

goods and services and maintain accountability due to over-bureaucratisation and rent seeking in the governmental process (Zafarullah and Huque, 2001; McCourt, 2012).

Federalism was established in most of the developing countries such as in Africa in the post-colonial period not only to promote national unity but also to institute a system of governance. Nonetheless, the practices of federalism in Africa did not appear to have positive effects (Eghosa-Osaghae, 2004). Despite that, the concept of federalism became popular in both developed and developing countries after World War II in balancing the power structure between federal and state or lower-level governments, maintaining a governing system, and strengthening institutional capacity (Keating, 2007). Welch et al. (2012) express that much as half of the world's territory was governed by federalism by the end of the 1960s. As a result, all levels of government were able to coordinate their actions in resolving national problems like the economic crises and the civil rights struggles. By the mid-1980s, innovative methods of governance, including decentralisation and people's participation, emerged as dominant paradigms (Hood, 1995; Moore, 1995; Dunleavy et al., 2006; Stoker, 2006; Pollitt and Bouckaert, 2011). These allowed citizens and governments to work together in implementing policies and programs and supporting networks and linkages.

Paudel and Sapkota (2018) state that each country gradually adopted federalism to serve different purposes. For example, the United States adopted the federal principle to safeguard the population from external attacks and to create wealth by increasing trade. Switzerland implemented it to exercise participatory democracy by establishing a representative system at the local level. Likewise, Brazil decentralised the functions of the existing centralised state. In Nepal, the space for federalism expanded after the implementation of the Comprehensive Peace Accord in 2006 envisioning to promote power-sharing, address ethnic and caste-based discrimination, integrate development programs, and scale-up local economic growth (Acharya, 2018a). Nepal is now devolving power to the federal, state, and local levels by launching participatory democracy. This has contributed to ending discrimination based on ethnicity, language, gender, religion, class, and regional and local imbalances.

In 2015, the federal Constitution was promulgated, which projected new forms of competition, created new methods of public management, and generated new governing codes for central-local relations (Acharya, 2018b). The constitution allows three levels of governments: federal, province, and local to facilitate the devolution of power to the local government system (LGS) and other state organisations and specify local governments as the units closest to the grassroots (Government of Nepal, 2015). In 2017, the Government of Nepal decided to implement a major territorial reform of LGS by creating over 700 local government units (LGUs) based on the 'principle of subsidiarity' and 'economies of scale.' Besides, these LGUs were granted autonomy to undertake constitutionally mandated legislative, executive and judicial functions encompassing 22 exclusive and 15 concurrent rights (Government of Nepal, 2015). To execute these, the government conducted local level elections and promulgated a new Act - "Local Governance Operation Act 2017" (LGOA) to drive the local government effectively. These practices, to a substantial extent, helped improve the quality of life, reduce social and economic inequalities, and enhance rapport between people and public institutions (Dhungel, 2017). However, the protracted absence of elected representation and extended control of the central bureaucracy have dampened power-sharing and constrained service delivery at the local level. Similarly, the capacity of LGS to operationalise the constitutionally sanctioned powers and the LGOA 2017 was depleted due to the protracted political transition from monarchy to a republic and low institutional and human resource readiness and efficiency of the LGSs. The functional capacity of local governments appeared fairly weak, which is particularly remarkable in intergovernmental relations. There has also been inadequate legislation and institutional frameworks, human resources management, accounting and procurement systems, and revenue administration (Acharya, 2018b). In this backdrop, this study aims to explore if the local government units are empowered enough to 
play their constitutional roles and engage in development activities at the grassroots. The focus is on the institutionalisation of federalism, its implications for local governance, and the capacity of local authorities to effectively deliver public services at the doorsteps of the people.

Institutionalising federalism in

Nepal

\section{Federalism, governance and service delivery: conceptual indicators}

Many authors (Burgess, 2005; Paleker, 2006; Elazar, 1995; Rath, 1978) explain that federalism is a mode of political association of different levels of governments and various interest groups and actors to co-ordinate and collaborate, yet function independently. Federalism seeks to divide the power structure in a planned manner within a comprehensive political system to maintain political integrity through negotiations and bargaining (Riker, 1964). Ostram (1991) illustrates that federalism is not just a form of government, but a method for solving problems. It is a way of life, which provides representational democracy with the scope for greater political participation and power-sharing among different levels of governments - federal, province and local. Each level has its own institutional set up independent of each other that directly concerns the people (Rath, 1978). Federalism is a prospect, a movement and an agreement for nation building. It provides for a self-sustainable and representational institutional mechanism, shared political understanding, harmonious "partnership," and an enabling environment for peoples' engagement in development and service delivery (Burgess, 2005; Shah, 2007).

In the neoliberal structure, federalism combines partial self-government with partial shared government through constitutional mechanisms, which encompasses more marketoriented public policies and distribute power vertically and horizontally between different levels of government, each with their respective roles and responsibilities. Its focus is on "self-rule," "shared rule" and responsiveness to citizens' demands and aspirations, historical traditions and social practices (Shah, 2007; Watts, 2002; Harmes, 2007).

Governance, on the other hand, is a system or a set of principles that regulates public affairs by applying approaches that are participatory, inclusive, responsive, and accountable (Gisselquist, 2012). Based on concrete policies and legal guidelines, it manages the societal, political, economic and administrative tasks of government (Rhodes, 1996). Governance is a response to disjointed, bureaucratised and politicised administrative structures and heightened corruption and clientelism within the political space (Zafarullah and Huque, 2001). In the 1980s, the move from the conventional public administration model to the New Public Management paradigm (Hood, 1991), sought to remove administrative dysfunctionality and apathetic bureaucratic behaviour through reform and revitalisation and to widen the governing space by shifting the emphasis from state control to alternative participants, such as non-state actors and institutions, the market and the private domain. This move not only elongated the perimeter of governance but also broadened the scope for interaction among networks across a range of sectors (Rhodes, 1996; Kim, 2006; Bouckaert et al., 2010). This process contributed to a shift from government to governance because of the continued presence and activism of a diverse group of policy actors from the public and nonstate sectors at several points in the policy process (Sørensen and Torfing, 2007; Osborne, 2010). The overwhelming rise of the third sector in the early 1980s compelled governments and global aid agencies to change their roles and cooperate with non-governmental agencies in improving ways of uplifting people's livelihood at the local level in the developing countries (Lathaa and Kotte, 2011). This not only ensured citizens' political rights but also enabled their participation in the service delivery mechanism (Acharya, 2014).

The multi-dimensionality of public sector governance in its multi-institutional and multilayered avatar is also attributable to local governance for the pursuit of efficiency, effectiveness, transparency, accountability, rule-of-law and human rights (Zafarullah and 
PAP

23,2

128

Huque, 2001). With blurred boundaries between the public and private domains, multiple actors in a pluralist setting at the local level can contribute their ideas, knowledge and resources to change governance from being state-centric to society-directed. In such an arrangement, reciprocal relations between institutions involved in collective action may be induced through autonomous self-governing networks (Rhodes, 1996; Stoker, 1998; Kim, 2006). Local government has the wherewithal to facilitate participatory democracy and connect citizens directly to issues that affect them, such as poverty reduction and better access to services (Stoker, 1998; Panday, 2018).

However, realities do not always follow the desired path as public administrators are influenced by complex constellations of institutions, intricate and often convoluted legal charters (Denhardt and Denhardt, 2000; Mongkol, 2011). Most governance practices are primarily based on the donor-driven bureaucratic apathy that do not cope with unpredictable market forces and unable to comply with regulatory directives (Fatile and Adejuwon, 2010). Archaic administrative practices, still in vogue in many developing countries, debilitate the delivery of services to the people (Sarker, 2005).

Local governance as an instrument to connect the people and the government focuses on decentralisation, i.e., transfer of authority and responsibility to the lower tiers for enhancing service performance and effectiveness (Turner, 2012). It underscores people's awareness of their role in society and their rights and obligations in social and political life. It seeks to ensure the social accountability of service providers, orders and demands transparency of their actions and calls for a high degree of effectiveness of public service delivery (Ahmad, 2008). Many developing countries have failed to cope with these issues and in transforming society from social, political and economic standpoints due to significant degree of bureaucratisation, politicisation, and over-influence of imported ideas and practices (Zafarullah and Huque, 2012; Acharya, 2018a). In such a situation, federalism enables the change of the governing structure from "government" to "governance," and generate powersharing between each set of government (Levi-Faur, 2012). Even though Nepal's journey towards a "Federal Republic" has not been easy, the aspiration has yielded via the Constitutional Act of 1948 followed by the Interim Constitution of 1951. The first Jana Andolan (people's movement) 1990 brought a new avenue for the people to fulfil their hopes and aspirations (Lamsal, 2013).

Despite the new system of federalism and local governance creating more space for local democracy to foster and broaden people's participation in policymaking at different levels of government, the initiatives fell short of reaching the goals due to irregular or disorderly local elections for 'security' reasons. Consequently, local bodies continued to function as bureaucracies until 2017. In line with the new Constitution 2015, local authorities are bestowed with powers to set up additional functions, such as planning, taxation, registration and certification of births, marriages, etc. Nevertheless, the capacity of local government is weak or, at best, reasonable in terms of enhancing the rule of law, supplying quality service, and efficiently planning, monitoring and implementing local programs and projects. As a result, people have become doubtful about the effectiveness of local governance (Acharya, 2018a).

\section{Research methodology}

This study is based on primary qualitative information, which was collected purposively from five selected municipalities in Nepal: Tulshipur, Lamahi, Chandragri, Dhulikhel, and Duhabi. The rationale for choosing the five municipalities was based on the delivery of functional services, public expenditure, preparation of local laws in conformity to constitutional obligations, and efforts at enforcing taxation as internal revenue. Responses to open-ended questionnaires were obtained from mayors, deputy mayors, ward 
chairpersons and members (particularly women and Dalits), municipality office staff, and civil society representatives. The primary data collection methods included key informant interviews (KII), focus group discussions (FGD), and personal observation. Information collected through one method was cross verified. This strategy helped to triangulate the data and ensure its validity and reliability. To complement and supplement the research, the participatory observation method was also used to interpret the findings obtained from the other methods. It is essential to mention that one of the researchers being a native of Nepal had "access to a depth and breadth of the culture's deep background" (Tracy, 2013, p. 107) but refrained from being biased in his reporting.

In total, $50 \mathrm{KII}$ and 10 FGDs were conducted in the five municipalities in SeptemberOctober 2019. Of KIIs, half were female to ensure gender balance. To measure the reliability of local-level responses, interviews and FGDs were conducted with 15 national level key informants, based on their contribution and experience in local governance and service delivery. These interviews designed to gather the opinions and commitment of the federal government towards local governance, capacity development, and local service delivery, focused on the existing power and functions of local authorities. Issues covered include: (a) organisation of the powers and functions of local government bodies; (b) formulation and implementation of inclusive plans and the budgeting process; (c) operationalisation of fiscal jurisdictions and effective resource mobilisation, and (d) preparation and execution of local acts and by-laws made by LGUs. The personal interviews were much easier to control-both in explaining the issues and extracting responses from participants. Interview duration averaged one hour, and the interviews were recorded electronically. Also, during data collection, one of the researchers was physically present and observed the modalities of local service delivery.

The rationale for the FGDs (two in each municipality) was to gain insight into people's perceptions concerning power and functions, resource mobilisation, and preparation of local regulations. Each FGD lasted approximately 90 minutes, and proceedings were electronically recorded. Data from FGDs and in-depth interviews were transcribed and coded according to the issues covered. Factual data for the study were based on official documents.

\section{Findings}

\section{Operationalising local governance}

Among other things, the 2015 Nepalese Constitution was designed to make LGS more responsive and participatory. Thus, to balance intergovernmental relations, the Constitution allocated 22 exclusive powers to local governments while assigning 15 concurrent powers to the federal, provincial and local levels (Government of Nepal, 2015). Furthermore, it provided for restructuring LGS resulting in the creation of over 750 local government units consisting of Gaunpalika (village government) and Nagarpalika (urban government). The justification for such power devolution is to create fair competition among and generate democratic practice in local government bodies, improve efficiency in local-level planning, reduce administrative cost, and make citizens more politically aware.

Complementing these constitutional entitlements, LGOA 2017 came into effect to create a strong legal foundation for institutionalising legislative, executive, and quasi-judicial practices in the LGS. These include organizing assembly meetings, setting management procedures, formulating plans and implementing them, carrying out judicial functions, and establishing financial jurisdictions. Also, coordination with other local, provincial and federal government bodies, monitoring activities of national and international non-governmental organisations, preparing budget and framing rules, regulations, and guidelines were covered.

From the interviews and FGDs, it became evident that the coordinator of the judicial committee prepared the list of community mediation centres and framed guidelines to resolve 
issues. The ward chairpersons prepared the budget and plan of their wards, collected and maintained data of households and records of public property. They also recommended and certified various legal documents related to personal incidents, land, house, citizenship, reconciliation and relationship. Likewise, chief administrative officers of local government performed their assigned duties such as formulating and implementing annual budgets and programs and maintaining records of all income, expenditure and fixed and moveable assets at the local level.

Despite these accomplishments, the local councils' effectiveness was low to moderate because of the lack of capacity in mobilising both fiscal and technical resources, building essential infrastructure, and framing appropriate laws and regulations. The shifts in authority led to a great deal of confusion among local representatives regarding their roles in planning and implementing development initiatives, managing human and financial resources, and maintaining a working relationship between the three tiers of government. Other factors included slow political transition, capacity constraints, legal ambiguities, and resource restraints (Acharya and Zafarullah, 2019). Similarly, the lack of clarity and understandings between different government entities regarding the scope and rights of the local government bodies endured. Some ward chairs expressed their inadequate understanding and awareness of their duties and responsibilities. Some women and Dalit members felt dejected:

Nobody has educated and oriented us about roles and duties. We are not able to read and understand legal procedures. They $[\mathrm{sic}]$ usually make judgments demeaning our educational status, which we do lack, and so that they do not consult us in making any decisions. We are excluded. If we were of no functional utility, why do they have this provision of reservation?

\section{Formulation and implementation of inclusive plans}

The LGOA authorises local government units to formulate periodic, annual, strategic and sectoral plans for local development. To expedite the process, the federal government has directed them to go about this task with inputs from the people. Similarly, these units are to prepare the mid-term expenditure framework, project resource availability, formulate financial policies and principles, and submit outcomes to the federal and provincial governments for their review. Respondents and FGD participants reported that in the annual planning and budgeting process, all local governments prioritised the programs related to financial growth and poverty reduction, employment generation, local resources mobilisation, gender equality and social inclusion, and environment protection. Chairs, vice chairs, executive board members, ward committees, council members, and sundry staff were all involved through the deliberative process in plan formulation. Seven steps constituted the plan formulation process, seven fewer than the previous practice. Similarly, different sets of criteria were adopted in prioritizing projects, such as those focusing on economic development and poverty reduction; cost-effectiveness, public participation and volunteering; local knowledge, skills and resource building; initiatives benefitting women, minorities, and the disadvantaged; and sustainable development, environmental conservation and protection. Projects are categorised into economic development; social development; infrastructure development; forestry, environment, and disaster management; and governance and institutional development.

To complete the planning process, the federal government ensures a strict timeline at each step comprised of different activities (Table 1).

A participant in one of the FGDs elucidated the changed context and effectiveness of the planning process at the local level involving a road project:

No budget was allocated for this road for the last three years. In the past, the budgetary process was not transparent, and no one had faith in the local government planning. Our voices could not reach 


\begin{tabular}{|c|c|c|}
\hline Step & Period & Activity \\
\hline 1 & January- mid April & $\begin{array}{l}\text { Each local government units (LGUs) completes budget pre-preparation, } \\
\text { submits a report on revenue projection and receives a budgetary allocation } \\
\text { from the federal and provincial governments in mid-March and mid-April } \\
\text { respectively }\end{array}$ \\
\hline 2 & January-mid May & $\begin{array}{l}\text { Based on the size of administrative area, size of population, human } \\
\text { development index of the local governments, federal and provincial } \\
\text { governments forwarded the budget celling to local governments by the Mid-of } \\
\text { April. Local governments review the ceilings of federal and provincial } \\
\text { governments, and project the overall sources of income, and allocate the } \\
\text { budget according to the sector and settlement projects by mid-May. }\end{array}$ \\
\hline 3 & Mid April- mid May & $\begin{array}{l}\text { LGUs undertake settlement level projects in consultation with local people } \\
\text { after obtaining approval from the ward committees. }\end{array}$ \\
\hline 4 & Mid May - end May & $\begin{array}{l}\text { Projects within each sector prioritised at the ward level and forwarded to the } \\
\text { municipal budget and plan formulation committee for submission to the } \\
\text { budget and plan formulation committee. }\end{array}$ \\
\hline 5 & $\begin{array}{l}\text { Mid May }-3^{\text {rd }} \text { week of } \\
\text { June }\end{array}$ & $\begin{array}{l}\text { The budget and plan formulation committee collects all projects from the } \\
\text { wards. It screens them according to five thematic sectors (Economic } \\
\text { Development, Social Development, Physical Infrastructure Development, } \\
\text { Forest environment and Disaster management, and Institutional } \\
\text { Development). After rigorous discussions and consultations with } \\
\text { stakeholders, the committee prepares a draft annual plan and forwards it to } \\
\text { the municipal board. }\end{array}$ \\
\hline 6 & Within $25^{\text {th }}$ June & $\begin{array}{l}\text { Municipal boards conduct meetings of the executive board for discussions, } \\
\text { updates and preparation of final draft. }\end{array}$ \\
\hline 7 & $4^{\text {th }}$ week of June & $\begin{array}{l}\text { Municipal boards, after consultation with local citizens, sectoral officers, local } \\
\text { organisations, and community groups, the deputy mayor/vice-chair or any } \\
\text { member designated by the executive shall present the programme and budget } \\
\text { estimates for the next fiscal year within } 25 \text { th June of every year before the } \\
\text { Assembly meeting. The Assembly complete discussion on the programme } \\
\text { and budget tabled within } 15 \text { days by developing a schedule for it. Upon } \\
\text { conclusion of the discussion, the assembly shall endorse the budget or send it } \\
\text { to the executive along with suggestions. The executive board again review the } \\
\text { programme and budget received along with suggestions from the assembly. } \\
\text { Again, the programme and budget with necessary amendments are tabled } \\
\text { before the assembly within five days. The assembly endorses the programme } \\
\text { and budget submitted by mid-July of the same year. }\end{array}$ \\
\hline
\end{tabular}

Source: Government of Nepal (2018b)

\section{Institutionalising federalism in Nepal}

Table 1.

Planning process timeline of the Local Government Operation Act 2017

the local government decision-making mechanism, although I was invited to the meetings. Now, the villagers have the opportunity to participate in the settlement level project selection and prioritisation process. We identified the road project as a major priority, arranged the resources, and made a commitment to public participation during implementation and management. This process enabled local governance at the community level.

Despite the procedural tasks, the state of Nepalese LGS has been unsettling (Dhungel, 2017). Three critical aspects of local governance can be acknowledged here, as these encompass the question of how difficult it was to implement the tasks mentioned earlier. First, the capacity of LGS is moderate or weak in formulating inclusive plans and implementing them. Almost all LGS bureaucratic staff are relatively unskilled or unwilling to perform their tasks (findings from primary data). Secondly, the coordination among local entities, between local and provincial governments, and between local and federal governments is inadequate in terms of planning and implementation. Thirdly, the extent of public participation has not been significant and is bereft of real dividends. While the existing structure of local government 
PAP

23,2

was instituted on the principles of representative democracy, there is no mechanism to ensure the participation of those who lost elections. Nonetheless, the new situation has opened new ways of engaging ordinary people in helping implement developmental projects and delivering services at the local level.

\section{Operationalising fiscal jurisdictions and resource mobilisation}

Fiscal policies and jurisdiction are vital constituents of fiscal federalism, and this includes the area covered, revenue sources, and inter-governmental financial relations (Bird and Vaillancourt, 2006). In Nepal, fiscal governance initiative was to strengthen LGS through efficient public resource mobilisation and create an enabling environment for private sector development. The 2015 Constitution authorised LGUs to formulate budgets and raise revenue through different forms of taxes (entertainment, advertisement, property, vehicle, house rent), land registration charges, intergovernmental fiscal transfer and others.

The local government bodies received funding from federal and provincial governments in various ways such as equalisation, revenue sharing, complementary (matching), and special grants, with the first two of these types being the most prominent. Current practice shows budget allocation to the local levels is based on the size of the administrative area (15 percent), size of population (70 percent), human development index (5 percent) and underdevelopment indicator (10 percent). There has been a significant increase in central allocation for the newly established local government units in the national budget after the implementation of the federalisation process. The trend shows that the sampled LGUs mobilised over two billion Nepali Rupees (1 Nepali Rupee is equivalent to US\$0.0085) as internal revenues, consolidated funds, equalisation and conditional grants, and royalty distribution in FY 2016/17. This figure increased to nearly six billion the following year (Acharya, 2018b).

These practices made locally elected municipal, village and ward councils not only powerful but also adequately resourced them and prepared the mechanism to move the country towards fiscal federalism. The fiscal responsibilities ranged from inter-governmental fiscal transfers, tax, and revenue assignment to sub-national government borrowing and expenditure assignment.

Despite these practices, fiscal federalisation has been a daunting challenge in devolving fiscal decision-making powers from the centre to the provincial and local governments. Although the 2015 Constitution authorised every local government unit to identify their needs, collect revenue, plan projects, layout budgets and implement these within their jurisdictions, problems were faced by LGUs in the generation, distribution and mobilisation of revenue. Some LGUs reported encountering difficulty in utilising local natural resources for generating revenue. As a deputy mayor expressed:

When we tried to use natural-based resources like river stones and sand, the District Coordination Committee (district level local government) objected having received instructions from the central ministry to collect the revenue and royalty, even though Local Government Operation Act, 2017 and other related acts granted that authority to the municipalities. Ambiguity and inconsistency in policies such as this deprive us of generating the needed revenue for development activities.

\section{Formulating and operationalising local legislations and by-laws}

To promote cooperation, coordination and coexistence at various levels, LGOA 2017 established the primacy of detailing the functions of local governments, including formulating laws relevant to the local context and needs. Thus, more than 30 local level Acts, by-laws and regulations have been formulated relating to a range of issues such as task execution, work division, decision-making, codes of conduct, public (rural and urban) 
assembly, and local taxation. Also, various laws and guidelines on planning and budgeting, and the formation of local level user committees were prepared. However, these legal mechanics could not be correctly implemented due to technical reasons, lack of coordination among the central level ministries, and continued intervention of central agencies.

The three-member municipal judiciary committee headed by the deputy mayor is one crucial body to directly adjudicate 13 different kind disputes and resolve additional 11 issues through the mediation process at the local level. Since women hold over 90 percent of the deputy mayoral positions, the effective functioning of this committee can play a vital role in addressing women's issues. However, a deputy chair of a sampled municipality cast her doubt about its effectiveness:

Nyayik Samitee (Judiciary Committee) has not yet begun its work. Although the central ministry forwarded a model guideline for Nyayik Samitee's, these could not be effective due to a lack of knowledge among members about the legal language and procedures at the local level. We have no idea whether our actions will lead to any improvement or create another cumbersome phase at the local level. People have many expectations, and we are still not sure if we can meet them.

\section{Discussion}

\section{Institutionalising federalism}

In the past, the unitary state in Nepal failed to maintain local governance and public accountability, engage citizens to formulate and implement inclusive plans, make and enforce fiscal jurisdictions and revenue administration, and promulgate and enforce the local legislations and by-laws (based on interviews with officials). While people's expectations intensified and made them assume that the federal system would work and be a cure-all for their problems, delivering services and providing equitable opportunities to the people were impeded because of the ethnic, lingual and cultural diversity of society. Many authors (Gellner, 2007; Hobswam, 1990) believe that federalism has tremendous potential to manage ethnically diverse communities through political recognition of cultural and ethnic pluralism. In the case of Nepal, however, this is yet to be noticed.

Secondly, the 'decentralised' development units created in the past have remained centralised as power and authority are not fully devolved to the sub-national levels. Thus, development could not reach every nook and corner of the country (based on FGDs). Nevertheless, advocates championed the potential gains from a decentralised system as it can close the gaps between the state and the people. As de Vries (2000, p. 197), points out, "Local diversity allows more easily for experimentation and innovation... [and] overcoming the limitations of centrally controlled national planning by delegating greater authority to officials working in the field, closer to the problems." In many countries, federalisation process contributes to reduced corruption by ensuring greater transparency and accountability in the decision-making process (Fisman and Gatti, 2002). Thirdly, the unitary system was unsuccessful in mobilizing the resources for sustainable development. On the other hand, both the federal and sub-national governments are constitutionally protected and, thus, the possibilities for independent decision making are stronger under federalism (Zimmermann and Finla, 2006).

Thirdly, the monarchical democracy in Nepal had failed in enabling people's participation in the decision-making process at the local, regional, or central levels (Dhakal, 2013; FGDs). To address structural-procedural gaps, federalism was seen to provide the wherewithal to create opportunities systematically, ensure access and inclusion of the marginalised, poor, backward and exploited, and guarantee citizens' rights and security, and effectively manage human resources at all levels (Karki, 2014). Gurung (2009) believes that federalism can create an inclusive state and counter the exclusionary, non-participatory, non-representative, and 
PAP

23,2

134

discriminatory nature of a highly centralised state and provide protection to a multi-diverse population. The Constitution guarantees that different cultural groups are sovereigns of the country and have the right to be culturally included in the mainstream.

Following the essence of the Constitution, the government attempted to institutionalise federalism in Nepal. First, the state was restructured into seven provinces based on population, resources, capability and identity. The main objective was to devolve constitutionally granted exclusive and concurrent powers to the lower levels so that centrally acquired state resources, facilities and institutions can reach the local people. Secondly, to avoid the possible conflicts and discrepancies related to tasks and functions at the three levels of government, work division was undertaken by unbundling the exclusive and concurrent powers of the federation. Thirdly, a high-level Federalism Implementation and Administration Restructuring Committee, was assigned the task of making policies and rules and coordinating the restructuring process under the leadership of the highest-ranked bureaucrat in the country (based on interviews).

The restructure was to equip the lower-level governments with self-decision-making power to exercise executive, legislative and judicial functions and be responsible for a wide range of service delivery and development functions. However, Madhes-based political parties and some identity-related activists disagreed with the new Constitution and the federalisation process over the names and number of provinces, power and resources, electoral representation, affirmative action plans, constituency delineation, and citizenshiprelated issues. These pushed the Madheshi political parties to resort to violence and create a blockade along the Nepal-India border. The government faced stiff opposition in Parliament when it sought an amendment to the existing scheme (based on interviews with Elected Representatives).

\section{Local government capacity}

In Nepal, the constitution devolves 22 exclusive and 15 concurrent powers and responsibilities to the local governments. Both state organisations and non-state partners have been directly involved in carrying out these rights and functions. Concurrently, LGOA 2017 created avenues for capacity development relevant to people, institutions, and policymaking/implementation. This contributed to the formulation of policies, plans, and programs linked to local self-governance, rural and community development, operationalise local legislations, by-laws, fiscal jurisdictions and resource mobilisation, and other sectorrelated issues. Secondly, LGUs can now conduct training and research and mobilise people to partake in decision making and coordinating functions in the local government sphere. These have helped enhance the capacity of elected representatives in institutional development, management of information systems, and fiscal administration. However, these programs are run with incoherent strategies and inept coordination that thwart capacity for expansion. Furthermore, a considerable gap in terms of knowledge, skills, and power between the central and local government personnel lessened the confidence of LGU staff (based on FGDs). Consequently, local employees became passive service providers and unsuccessful in promoting democratic and inclusive development.

Although a plethora of laws, regulations, and directives was to pave the way towards effective implementation of executive, legislative and judicial functions and authorize the LGS to carry out a considerable number of listed tasks, the degree of confusion regarding duties and responsibilities remained acute among the local representatives (based on interviews with Local Councillors).

Currently, in Nepal, LGUs mobilise large chunks of resources through fiscal transfer (Khadka, 2016). However, this alone cannot deliver the desired results, until the capacity of LGUs are developed. Weak human capability and the absence of desired expertise in 
implementing development programs result in poor work quality and delay in delivery. The development partners have urged the government to focus on enhancing local government capacity through training in local governance, leadership, accountability, office administration and management, and social inclusion (Government of Nepal, 2018a; interviews with officials in Nepal). However, the absence of concrete national policies and strategies, over-politicisation and political favouritism have stymied attempts to bring about a tangible impact on capacity development of local governance.

Institutionalising federalism in Nepal

\section{Commitment of actors}

The ongoing federalisation and governance process in Nepal have the support of political parties, bureaucracy, civil society, local communities and development partners (based on interviews). The political parties consider federalism as a system that requires the state to be more inclusive in creating trust between the people and the government. Most political parties pledged their commitment to federalism through their manifestos leading up to the various elections (Paudel and Pahari, 2020; interviews and FGDs). The political parties have articulated their commitment to setting up several federal units, ensuring equal representation of women and people belonging to different ethnic and language groups and regions in political positions, resource sharing, and devolution of power and functions.

Despite the post-1990 political upheavals, the commitment of political parties towards federalism has not abated. However, they are considered neophytes and inexperienced in implementing federalism. On the other hand, politicians suspect that the present state mechanism is merely a pocket fund that can be used or misused to their advantage. Powerseeking behaviour and political instability portray Nepal as a state in which political parties, through massive unlawful and non-transparent activities, can shape federalism to their advantage (Upadhyay, 2015).

As for the bureaucratic apparatus, to some extent, it is empowered to expand its reach, increase technical expertise, and tighten its control over information and resources. As a result, the bureaucracy has turned out to be overwhelmingly powerful due to its profound influence and control over political institutions (based on FGDs). On the other hand, the bureaucracy has exposed itself to unaccountable and unethical behaviour. Even though the bureaucratic role had been productive in-service delivery and managing the local governmental system before the establishment of elective bodies at the local level, it has now become imperative for the bureaucracy to embrace the newer practices of federalism to institutionalise the system firmly. The government is under pressure to manage about 87,000 civil servants in the restructured public sector. Many public servants are reluctant to move to the provincial and local levels, mainly due to the remoteness of their workplaces (Acharya, $2018 \mathrm{~b}$; interviews). On the other hand, they are also chided for being restrictive, weak and poor in performing their functions not only because of systemic deficiency but also for their self-centric mindset, demotivated approach, rent-seeking behaviour, status-oriented outlook, undeniable loyalty to political parties and for sheltering themselves from control and accountability regimes.

The role of the development partners in the past appeared both as enabler and inhibiter. Nevertheless, their contribution was quite remarkable before the new LGS came into operation when several development partners were collectively engaged in supporting the Nepalese government's initiatives at strengthening local democracy and promoting social mobilisation and inclusion. The people were encouraged to participate in the local governance process through Ward Citizen Forums and Citizen Awareness Centres (based on FGDs). Now, they are active in operationalizing federalism. Nepal's international development partners are committed to supporting the government in its work against corruption by helping improve transparency and accountability at all levels and organisations. 


\section{Conclusion}

Nepali society is undergoing enormous social, cultural, political, and economic changes. Such kind of change has been more rapid since the beginning of the new political order in 1990, followed by a significant period of change from 2006 to 2017. Apparently, this kind of change has given the people freedom of expression, strengthened human and socio-political rights, and increased people's access to public services. The ordinary people, now being more aware of their rights, privileges and obligations, can raise their voices against social and political malevolence and create more meaningful space in social, political, and economic affairs. These changes have contributed significantly to enhancing people's identity and broadening their political choices.

The Local Government Operation Act 2017 (Government of Nepal, 2018b) looks to promote cooperativeness, co-existence, and coordination among the different levels of governments. However, it is not without its flaws. It limits the sources of revenue, given the extensive number of functions local government bodies are supposed to perform. Secondly, it does not address the capacity-deficit among elected representatives and administrative personnel. Thirdly, some functions, which were unbundled by the federal government, lack clear description and local officials are insufficiently prepared to carry out the diverse range of activities. Finally, central control is firmly held through centrally appointed officers who are to provide leadership and direct local administration. They often lack the motivation and the temperament in providing directions to the field personnel involved in implementing decisions. Central-local relations, despite the reforms, is still lop-sided with regulating authority concentrated in the centre.

Given all the unsettled issues, federalism in Nepal is tottering through its journey. The implementation of the regulating statute is staggering; politicians are diffident in providing the required leadership and keen to maintain the status quo; bureaucrats are self-effacing and unwilling to take initiatives; development partners clamorous to get things done at a quick pace, while the people remain cynical about the government's seriousness in advancing governance at the grassroots. Structural, functional and behavioural issues have dented the federalizing process, which is moving at a slow pace amidst predicaments. A lot needs to be done to fully institutionalise the decentralised system as enshrined in the country's Constitution. On their part, the LGUs are expected to be more responsive to the demands of the community and fulfil their political and social obligations. Time will tell if federalism has been able to serve the purposes for which it was installed - whether it can create a noncentralised inclusive state with real autonomy enjoyed by the locally elected bodies to serve the people better.

\section{References}

Acharya, K.K. (2014), "Relevance of community governance for basic service delivery in Nepal: An empirical study", unpublished doctoral thesis, University of New England, Australia.

Acharya, K.K. (2018a), "The capacity of local governments in Nepal: from government to governance and governability?", Asia Pacific Journal of Public Administration, Vol. 40 No. 3, pp. 186-197.

Acharya, K.K. (2018b), "Local governance restructuring in Nepal: from government to governmentality", Dhaulagiri Journal of Sociology and Anthropology, Vol. 12, pp. 37-49.

Acharya, K.K. and Zafarullah, H. (2019), "Community governance and service delivery in Nepal: an assessment of influencing factors", Commonwealth Journal of Local Governance, Vol. 21, pp. 1-22.

Ahmad, R. (2008), "Governance, social accountability and the civil society", Journal of Administration and Governance, Vol. 3 No. 1, pp. 10-21.

Bird, R.M. and Vaillancourt, F. (2006), Perspectives on Fiscal Federalism, The World Bank, Washington DC. 
Bouckaert, G., Peters, G.B. and Verhoest, K. (2010), The Coordination of Public Sector Organisations: Shifting Patterns of Public Management, Palgrave Macmillan, Basingstoke.

Burgess, M. (2005), Comparative Federalism, Routledge, New York, NY.

Campbell, A.K. (1972), "Old and new public administration in the 1970s", Public Administration Review, Vol. 32 No. 4, pp. 343-347.

de Vries, M.S. (2000), "The rise and fall of decentralisation: A comparative analysis of arguments and practices in European countries", European Journal of Political Research, Vol. 38, pp. 193-224.

Denhardt, R.B. and Denhardt, J.V. (2000), "The new public service: serving rather than steering", Public Administration Review, Vol. 60 No. 6, pp. 549-559.

Dhakal, S. (2013), "Democracy, democracies and democracy discourses in Nepal: an anthropologist's engagement”, Dhaulagiri Journal of Sociology and Anthropology, Vol. 7, pp. 133-155.

Dhungel, S. (2017), "Unique local governance model”, New Spotlight, Vol. 10 No. 22, available at: https:// www.spotlightnepal.com/2017/07/09/unique-local-governance-model/ (accessed 11 August 2018).

Dunleavy, P., Margetts, H., Bastow, S. and Tinkler, J. (2006), "New Public Management is dead-long live digital-era governance", Journal of Public Administration Research and Theory, Vol. 16, pp. 467-494.

Eghosa-Osaghae, E. (2004), "Federalism and the management of diversity in Africa", Identity, culture and politics, Vol. 5 No. 1/2, pp. 162-178.

Elazar, D.J. (1995), Federalism: An Overview, Human Sciences Research Council (HSRC), Pretoria.

Escobar, A. (1988), "Power and visibility: development and the invention and management of the Third World”, Cultural Anthropology, Vol. 3 No. 4, pp. 428-443.

Esteban, A. (2009), Integrated Governance, Risk and Compliance: Enabling Transparency, Accountability and Integrity, SAI Global, Sydney.

Fatile, J.O. and Adejuwon, K.D. (2010), "Public sector reform in Africa: Issues, lessons and future directions", Journal of Sustainable Development in Africa, Vol. 12 No. 8, pp. 145-157.

Fisman, R. and Gatti, R. (2002), "Decentralisation and corruption: evidence across countries", Journal of Public Economics, Vol. 83 No. 3, pp. 325-345.

Gellner, D.N. (2007), "Caste, ethnicity and inequality in Nepal", Economic and Political Weekly, Vol. XLLII No. 20, pp. 1823-1828.

Gisselquist, R.M. (2012), "Good Governance as a Concept, and Why This Matters for Development Policy”, Working Paper No. 2012/30, United Nations University, Helsinki.

Government of Nepal (1990), The Constitution of Nepal, Nepal Law Commission, Kathmandu.

Government of Nepal (2015), The Constitution of Nepal, Nepal Law Commission, Kathmandu.

Government of Nepal (2018a), Provincial and Local Governance Support Programme (PLGSP): Programme Document (January 2019-July 2023), Ministry of Federal Affairs and General Administration, Kathmandu.

Government of Nepal (2018b), The Local Government Operation Act 2017, Nepal Law Commission, Kathmandu.

Gurung, O. (2009), "Social inclusion: policies and practices in Nepal", Occasional Papers in Sociology and Anthropology, Vol. 11, pp. 1-15.

Harmes, A. (2007), "The political economy of open federalism”, Canadian Journal of Political Science, Vol. 40 No. 2, pp. 417-437.

Hobsbawm, E. (1990), Nations and nationalism since 1780, Cambridge University Press, Cambridge.

Hood, C. (1991), “A public management for all seasons?”, Public Administration, Vol. 69 No. 1, pp. 3-19.

Hood, C. (1995), "The 'New Public Management' in the 1980s: variations on a theme”, Accounting, Organisations and Society, Vol. 20 No. 2/3, pp. 93-109.
Institutionalising federalism in

Nepal 
PAP

23,2

Karki, B. (2014), "State restructuring and federalism discourse in Nepal", in Karki, B. and Edrisinha, R. (Eds.), The Federalism Debate in Nepal, UNDP, Kathmandu, pp. 1-22.

Keating, M. (2007), Federalism and the Balance of Power in European States, OECD, Paris.

Khadka, R.B. (2016), "An overview of federal fiscal system in Nepal”, Journal of Fiscal Federalism, Vol. 1 No. 1, pp. 46-54.

Kim, J. (2006), "Networks, network governance, and networked networks", International Review of Public Administration, Vol. 11 No. 1, pp. 19-34.

Kotz, D.M. (2002), “Globalisation and neoliberalism”, Rethinking Marxism, Vol. 14 No. 2, pp. 64-79.

Lamsal, A.K. (2013), "Mass revolution and end of the cultural institution in Nepal", Researcher, Vol. 1 No. 2, pp. 11-22.

Lathaa, K.L. and Kotte, K. (2011), "Non-government organisations: problems and remedies in India", Serbian Journal of Management, Vol. 6 No. 1, pp. 109-121.

Levi-Faur, D. (2012), "From 'Big Government' to 'Big Governance'?", in Levi-Faur, D. (Ed.), The Oxford Handbook of Governance, Oxford University Press, New York, NY, pp. 28-42.

McCourt, W. (2012), "Can top-down and bottom-up be reconciled? Electoral competition and service delivery in Malaysia", World Development, Vol. 40 No. 11, pp. 2329-2341.

Mongkol, K. (2011), "The critical review of new public management model and its criticisms", Research Journal of Business Management, Vol. 5 No. 1, pp. 35-48.

Moore, M. (1995), Creating Public Value: Strategic Management in Government, Harvard University Press, London.

Osborne, S.P. (2010), “Delivering public services: time for a new theory?”, Public Management Review, Vol. 12 No. 1, pp. 1-10.

Ostrom, V. (1991), American Federalism: Constituting a Self-Governing Society, ICS, San Francisco.

Paleker, S.A. (2006), "Federalism: a conceptual analysis", The Indian Journal of Political Science, Vol. 67 No. 2, pp. 303-310.

Panday, P. (2018), "Making innovations work: local government-NGO partnership and collaborative governance in rural Bangladesh", Development in Practice, Vol. 28 No. 1, pp. 125-137.

Pankaj, A.K (2007), "Review article: State-led development of developing societies", Journal of Asian and African Studies, Vol. 42 No. 3/4, pp. 321-327.

Paudel, B. and Sapkota, K.P. (2018), Local Levels in Federalism: Constitutional Provisions and the State of Implementation, Swatantra Nagarik Sanjal Nepal, Kathmandu.

Paudel, N.R. and Pahari, S. (2020), "Local election in Nepal: means for ensuring electoral accountability", Journal of APF Command and Staff College, Vol. 3 No. 1, pp. 35-48.

Peters, B.G. (2001), The Future of Governing, University Press of Kansas, Lawrence, KS.

Pollitt, C. and Bouckaert, G. (2011), Public Management Reform: A Comparative Analysis, Oxford University Press, Oxford.

Rath, S. (1978), "Federalism: a conceptual analysis", The Indian Journal of Political Science, Vol. 39 No. 4, pp. 573-586.

Rhodes, R. (1996), "The new governance: governing without government", Political Studies, Vol. 44 No. 4, pp. 652-667.

Riker, W.H. (1964), Federalism: Origin, Operation, Significance, Little Brown, Boston.

Sarker, A. (2005), "New public management, service provision and non-governmental organisations in Bangladesh", Public Organisation Review, Vol. 5 No. 3, pp. 249-271.

Shah, A. (2007), "Introduction: principles of fiscal federalism", in Shah, A. and Kincaid, J. (Eds.), The Practice of Fiscal Federalism: Comparative Perspectives, McGill-Queen's University Press, Montreal, pp. 3-42. 
Sørensen, E. and Torfing, J. (2007), "Introduction governance network research: towards a second generation”, in Sørensen, E. and Torfing, J. (Eds.), Theories of Democratic Network Governance, Palgrave Macmillan, London, pp. 1-20.

Stoker, G. (1998), "Governance as theory: five propositions", International Social Science Journal, Vol. 50 No. 155 , pp. 17-28.

Stoker, G. (2006), "Public value management: a new narrative for networked governance?", American Review of Public Administration, Vol. 36 No. 1, pp. 41-57.

Tracy, S.J. (2013), Qualitative Research Methods, Wiley-Blackwell, Oxford.

Turner, M. (2012), "Decentralisation, politics and service delivery", Public Management Review, Vol. 14 No. 2, pp. 197-215.

Upadhyay, P. (2015), "Reforms and changes in Nepal: political-sociological perspectives on state restructuring process in the post-democratic period", Crossing the Border: International Journal of Interdisciplinary Studies, Vol. 3 No. 1, pp. 81-98.

Watts, R.L. (2002), Comparing Federal Systems, McGill-McQueen's University Press, Montreal.

Welch, S., Gruhl, J., Comer, J. and Rigdon, S. (2012), Understanding American Government, Thompson Learning Academic Centre, London.

Zafarullah, H. and Huque, A.S. (2001), "Public management for good governance: reforms, regimes, and reality in Bangladesh", International Journal of Public Administration, Vol. 24 No. 12, pp. 1379-1403.

Zafarullah, H. and Huque, A.S. (2012), Managing Development in a Globalised World: Concepts, Processes, Institutions, CRC Press, New York, NY.

Zimmermann, A. and Finla, L. (2006), "Reforming federalism: a proposal for strengthening the Australian federation", Monash University Law Review, Vol. 37 No. 2, pp. 190-231.

\section{About the authors}

Keshav Kumar Acharya is a Local Governance and Capacity Development Advisor of German Development Cooperation of Nepal. His main interests are in governance, public policy, capacity development, result-based planning, service delivery, peacebuilding, community development, and disaster management. He holds a PhD from the University of New England. As a development expert, he worked in different projects of UNDP and other organisations in Nepal, Thailand, and Australia for more than 20 years. He has authored books, journal articles and research papers, which have been published in peer-reviewed international journals and as book chapters.

Habib Zafarullah is an adjunct faculty in the Division of Sociology at the University of New England, Australia. He has a PhD in Public Administration from the University of Sydney. His areas of academic interest are in democratic governance, comparative bureaucracy, public policy and administration, and international development and has published extensively in these areas. Some of his recent books include: Colonial Bureaucracies (2014), Managing Development in a Globalized World (2012) and International Development Governance (2006) (the latter two with A.S. Huque). He was the editor of Politics, Administration and Change, an international social science journal, for 25 years and currently is Editor-in-chief of the Journal of Governance, Security and Development. Habib Zafarullah is the corresponding author and can be contacted at: hzafarul@une.edu.au

For instructions on how to order reprints of this article, please visit our website:

www.emeraldgrouppublishing.com/licensing/reprints.htm

Or contact us for further details: permissions@emeraldinsight.com 